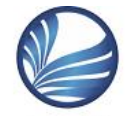

ELK

Asia Pacific Journals

www.elkjournals.com

\title{
STUDY OF NANO-EMBEDMENTS ON ORDINARY CEMENT COMPOSITES
}

Mainak Ghosal
Research Scholar,
Indian Institute of Engineering Science \& Technology
West Bengal, India

Mainak Ghosal

West Bengal, India

\author{
Prof.Arun Kumar Chakraborty \\ Associate Professor, Dept. of Civil Engineering, \\ Indian Institute of Engineering Science \& Technology \\ West Bengal, India
}

\begin{abstract}
One of the most interesting research fields of recent time is the study of reaction mechanism of nano embedments in cement composites. Cement composites prepared with river sand as per Indian standards with and without Nanoparticles showed an increase of $31 \%$ in compressive strength at 7 days \& $32 \%$ at 28 days \& $59 \%$ at 90 days respectively. However, the gain fell to $8 \%$ at 180 days when compared to ordinary cement composites at $0.75 \%$ nS optimization w.r.to cement wt. Similarly, Nano Carbon tube embedments showed a decrease of $16 \%$ at 7 days, 37\% increase at 28 days, 14\% increase at 90 days \& 3\% increase at 180 days when compared to ordinary controlled cement composite after dispersion in Super Plasticizer-Poly Carboxylate Ether at 0.02\% optimization of Nanotubes w.r.to cement wt.
\end{abstract}

Keywords: Embedments, Cement, Nano, Strength, Tubes

\subsection{INTRODUCTION}

Nanoparticles were found having applications in various fields of life starting from energy sector to electronics to civilconstruction to textiles. The emergence of this technology was caused in 1980s due to the convergence of experimental advances like invention of Scanning Tunneling Microscopy (1981) and discovery of Fullerenes (1985) which lead to the awarding of the Nobel Prize in 2010 in Physics for the discovery of Fullerenes. In fact it was Nanotechnology that allowed creation of iPods, iPhones and all sort of these "i" products which in a way completely changed the IT and electronics sectors. So why can't applications of Nanotechnology do the same to our conservative construction sector now? There have been many successful NT based applications which could have been almost impossible without utility of nano sized particles. For example, anti-scratch paints, 


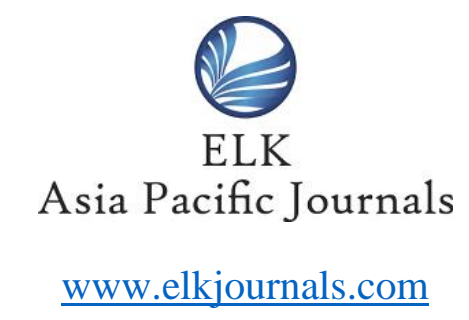

anti-bacterial

paints, anti-

fouling concrete, dirt repellant textiles, cloth es that need no ironing, non-reflective glasses, wonder drugs etc. are only the tip of the iceberg. It is a surprise to learn that the Romans and Chinese were using nanoparticles thousands of years ago. Carbon black the substance that makes our tyres black and improves the wear resistance of the rubber was known since 1920s. Of course they were not aware that they were using nanotechnology, as they had no control over particle size, or even any knowledge of the nanoscale as currently defined.

"Nanotechnology is the base technology of an industrial revolution in the 21st century. Those who control nanotechnology will lead the industry."

-- Michiharu Nakamura, Executive VP at Hitachi

Nano is a Greek word and means "Dwarf". Carbon Nanotubes was first discovered by Russian scientists L. V. Radushkevich \& V. M. Lukyanovich in 1952.
The Nanoparticle size which is below One billionth of a meter is produced as nanoadditives are from traditional cement, silica (quartzite sand) or even fly ash. For larger scale, nano-Silica (nS) [the first nanomaterial to be used in construction] are produced from

Vaporization of silica or by feeding worms with rice husk or by precipitation method

while techniques have been developed to produce nanotubes in sizeable quantities, including arc discharge, laser ablation, highpressure carbon monoxide disproportionation (HiPco), and chemical vapor deposition (CVD).

A Nano additive as cement replacement in very insignificant dosages changes the hydration kinetics of entire cementitious system resulting in the improvement in the compressive strength of paste, mortar and concrete. Additionally, the rheology of paste, mortar \& concrete is influenced with nanoadditions. It also improves the microstructure of the concrete system. Work presented by many authors reveals that the nano-additives 


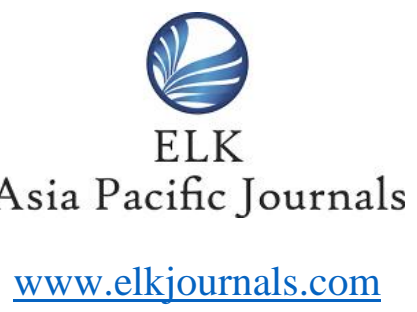

improve the performance of concrete resulting in High Performance Concrete (HPC) or Ultra High Performance Concrete (UHPC) and in turn making concrete durable. Though Nano-Silica (nS) is now commercially available in India but the production of Carbon Nano-Tubes (CNT) in the whole world is to the tune of several hundred Kilograms per year, thus making it very costly. So it is clear that the impact of nanotechnology on cementitious is at present mainly at the research level. These advances in scientific understanding need to be transferred into the field by introduction of technical and safety standards of the material used.

The first patent on nano-enabled cement was published in 1996 and since then it has seen an exponential rise after 2007. China has emerged as the major contributor in this area with $41 \%$ of global patents filings. The emergence of nanotechnology in cement industry has already shown a remarkable impact on mechanical and other properties of cementitious materials with patented commercial products such as NanoCrete, Cor-Tuf®, HuberCrete®, Alpol, NyconG Nano, TioCem, TxActive, MCSpecial DM etc. are already available in market.Naga Nanotech etc. apart from big commercial houses like Reliance, TataGroup, Mahindra \& Mahindra exploring NT options. Many scientists believe that R\&D in nanoscience and technology must be promoted at central and state universities since that allows an opportunity for students undertaking bachelors and masters programs. Accordingly, Dr Kalam, the nation's then president and renowned space scientist assumed the role of promoting nanotechnology at several national academic and other forums. His pro nanotechnology oratory and stance coupled with vision for establishing India as a "nanotechnology hub" has influenced policy makers and academia to strenuously emphasize on this emerging science and technology. The Budget allocation for (National Nano Science \& Technology Mission) NSTM amongst all the schemes in the 10th five year 


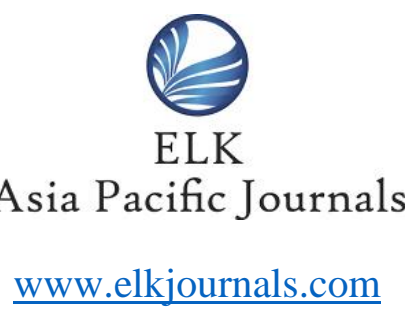

plan was second. Construction projects today are increasingly required to meet stringent building codes and energy regulations which is fuelling an industry transition to use the next generation nanomaterials. The Twelfth Five Year Plan emphasized use of new materials \& technology for the Ministry of Roads \& Surface Transport (MORSTH).) The emergence of nanotechnology in India has witnessed a diverse set of players ranging from domains like agriculture, water, health, energy, \& environment to industries like pharmaceuticals, automobiles, electronics, textiles, chemicals \& manufacturing (of which construction is a small part),IT \& biotechnology. Among the government agencies, besides Department of Science \&Technology (DST) other agencies include Council of Scientific \& Industrial Research (CSIR), Dept. of Bio-Technology (DBT), and agencies under Ministry of Information \& Communication Technology, Ministry of Family Health \& Welfare, Ministry of Defence, and Ministry of New \& Renewable Energy are engaged with the promotion of NT in terms of R\&D activities. Also there are private companies in India those are engaged in NT such as Beechems,NanoBeach,Monad Nanotech,Na noShell,NagaNanotech,Qtech Nanosystems, apart from big commercial houses like Reliance, Tata Group, Mahindra \& Mahindra, GoodYear, Bridgestone etc. are exploring NT options.

\subsection{LITERATURE REVIEW}

Belkowitz,S.J. $\quad$ \& $\quad$ Armentrout.D. ${ }^{1}$ developed relationships to distinguish the benefits when using different sizes of nanosilica $(\mathrm{nS})$ in cement hydration paste through experimenting \& measuring the heat of hydration of multiple mix designs and showed that as silica particles decreased in size with increased size distribution the C-S$\mathrm{H}$ became more rigid and in turn increasing the compressive strength.

Quercia,G. \& Brouwers,H.J.H ${ }^{2}$ aimed to present in their paper the $\mathrm{nS}$ production process from olivine 


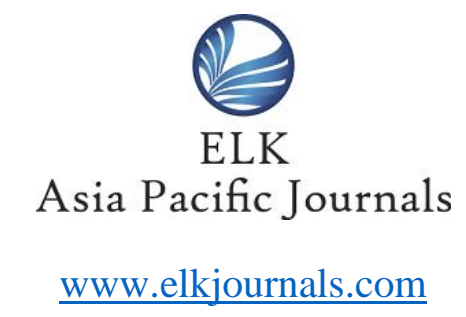

dissolution, their addition and their application in concrete.

Valipour.M et al $^{3}$ studied the influence of nS addition on properties of concrete when compared with silica fumes (SF) through measurement of compressive strength, electrical resistivity \& gas permeability. The results show that replacement of a portion of $\mathrm{SF}$ with $\mathrm{nS}$ is more active in early age due to larger specific surface \& fineness and will also improve the durability aspects of HPC.

Kumar,S. et $\mathbf{a l}^{4}$ discussed the effect of Multiwalled Carbon Nanotubes(MWCNT) on strength characteristics of hydrated Portland cement paste by mixing various proportions of MWCNT and found an increase in compressive and tensile strength of $15 \%$ and $36 \%$ at 28 days.

Maheswaran,S et $\mathbf{a l}^{5}$ attempted to highlight the influence of Ns towards pore filling effect and its pozzolonic activity with cement for improvement of mechanical properties and durability aspects. The paper also says that there is a scope for development of crack free concrete.

Yang, $\mathbf{H}^{6}$ presented the laboratory investigations that when nano silicon powder mixing content is $0.5 \%, 0.75 \%$ $\& 1.0 \%$ compared with ordinary concrete, the bending tensile strength at 28 days were increased by $3.2 \%, 7.5 \% \& 4.0 \%$ and the shrinkage rate at the same age reported increase by $75.5 \%, 127.1 \% \& 163.0 \%$.

Yuvraj, $\mathbf{S}^{7}$ described when $\mathrm{nS}$ is added it makes the concrete less alkaline as $\mathrm{C}-\mathrm{H}$ in concrete is reduced which reduces the corrosion of steel bars. He also added that more C-S-H is produced at the Nano scale thus increasing the compressive strength.

Abyaneh, M.R.J. et $\mathbf{a l}^{8}$ investigated the compressive strength, electrical resistivity and water absorption of the concrete containing $\mathrm{nS}$ and micro-silica at 7,14,28 days and reported that concrete with microsilica and $\mathrm{nS}$ have high compressive strength than with concrete with only micro-silica. He further deliberated that that specimens with 


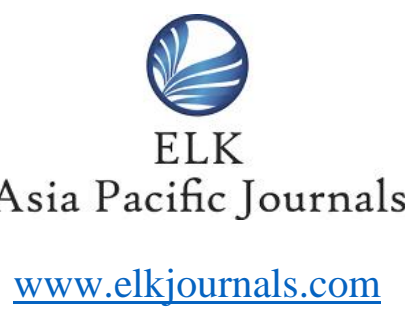

$2 \% \mathrm{nS}$ and $10 \%$ micro-silica have less water absorption and more electrical resistance in comparison with others.

Madhavi,T. et al $^{9}$ found an increase in compressive and split-tensile strengths of samples with increasing MWCNT.0.045\% of MWCNT has improved the 28 days compressive strength by $27 \%$ while the split tensile strength increased by $45 \%$.Crack pro pagation was reduced andwater absorption decreased by $17 \%$ at 28 days curing.

Rajmane, N.P. et al ${ }^{10}$ showed that $\mathrm{nS}$ cannot be used as an admixture to improve the microstructure of the cement composites (with and without $5 \% \mathrm{SF}$ ) at the w/c ratio of 0.5 .

\subsection{SCOPE OF PRESENT WORK}

The nano-Silica (nS) and Carbon-Nanotubes (Multi-walled, Industrial grade) are a product of nanotechnogy and are commercially available. The overall aim of the experimental program me of this research is to produce a workable high performance Cement composites that would provide both long-term and highearly-strength and that would meet the durability requirements of most practical constructions in an aggressive environment such as India.

\subsection{EXPERIMENTAL PROGRAMME -}

Materials used:

1. Cement - Ambuja OPC Types

2. Reinforcement Bar -- NA

3. Sone Aggregate -- NA

4. Fine Aggregate -- Natural (River) Sand

5. Water -- Drinking (Tap) Water

6. Chemical Admixture -- Chryso

7. Nano Additives -- Nano Silica (nS) \& Multi-Walled Carbon Nanotubes (MWNTs)

(I) The first test procedure involved testing Nano-Silica (XLP, XTX, XFxLa - Supplied by M/s BEECHEMS, Kanpur, India) in variable quantities $(0 \%$, $0.5 \%, 0.75 \%, 1.0 \%, 1.25 \%, 1.5 \%$ by cement wt.) in Ordinary Portland 


\author{
2 \\ ELK \\ Asia Pacific Journals \\ www.elkjournals.com
}

\section{Cement(OPC-Ambuja make) in a compression testing machine.}

Test Procedure(I):Mortar cubes of $70.7 \mathrm{mmX} 70.7 \mathrm{~mm} \times 70.7 \mathrm{~mm}$ dimensions are filled with 1 part of Cement +3 parts of River Sand with Water added, according to the standard formula $\mathrm{P}^{\text {ee }}=(\mathrm{P} / 4+3)(1$ part Cement +3 partsSand). Here $\mathrm{P}^{\text {ee }}=$ Quantity of water \& $\mathrm{P}=\mathrm{Consistency}$ of Cement used .i.e.

Amount of water used to make300gms cement paste to support a penetration of 5$7 \mathrm{~mm}$ in a standard Vicat mould with a Vicat needle. Now we would be testing the Compressive Strength of both composite \& ordinary Cement Mortar after 1day, 3days, 7days, 28days, 90days, 180days, 365days ordinary curing in a COMPRESSION CUBECRUSHING/TESTING M/C.

Mix Design (forOrdinary Portland Cement43 Grade Ambuja):

(A)For $0.0 \%$ Nano-Silica: Standard weight of Cement taken for 12 nos. Moulds $=12 \times 200=2400 \mathrm{gmsWeight}$ of River Sand(Zone-III) a/c to $1: 3::$ Cement:Sandratio $=3 X 12 X 200=7200$ gms. Weight of Water added $($ comes to $\quad$ be $)=(30 / 4$ $+3)(2400+7200) / 100=1008 \mathrm{gms}(\mathrm{ml}$.)*As $\mathrm{P}=30 \%$ (As Laboratory Test suggests )
(B)For $0.5 \%$ wt. of Nano-Silica w.r.to Cement wt.Standard weight of Cement taken for 12 nos. Moulds $=12$ X200=2400gmsWeight of River Sand a/c to $1: 3$ ratio $=3 X 12 X 200=7200 \mathrm{gms}$. Weight of Water added (comes to be) $=(30 / 4+3)$ $(2400+7200) / 100=1008 \mathrm{gms} \quad$ (ml.) $0.5 \%$ $\mathrm{XTX}=0.5 / 100 \mathrm{X} 2400=12 \mathrm{gms}$ of Nano-

Silica required $\equiv 29.5 \mathrm{gms}$ of $X T X \equiv 25.4 \mathrm{ml}$.of XTX.

(@ \% wt. of solid content in XTX=40.74\%; Density $(\mathrm{XTX})=1.16 \mathrm{gms} / \mathrm{cc}$. $)$ Net Water added $=1008-25.4=982.6 \mathrm{ml} . \sim 983 \mathrm{ml}$.

(C)For $0.75 \%$ wt. of Nano-Silica w.r.to Cement wt.Standard weight of Cement taken for 12 nos. Moulds $=12$ X200 $=2400 \mathrm{gms}$ Weight of River Sand a/c to $1: 3$ ratio $=3 X 12 X 200=7200$ gms. Weight of Water added (comes to be) $=(30 / 4+3)$ $(2400+7200) / 100=1008 \mathrm{gms} \quad(\mathrm{ml}) \quad 0.75 \$. $\mathrm{XTX}=0.75 / 100 \mathrm{X} 2400=18 \mathrm{gms}$ of Nano-

Silica required $\equiv \quad 44.18 \mathrm{gms}$ of XTX $\equiv 38.08 \mathrm{ml}$.of XTX.

(@ \% wt. of solid content in XTX=40.74\%; Density $(\mathrm{XTX})=1.16 \mathrm{gms} / \mathrm{cc}$. $)$ Net Water added $=1008-38=970 \mathrm{ml}$. 


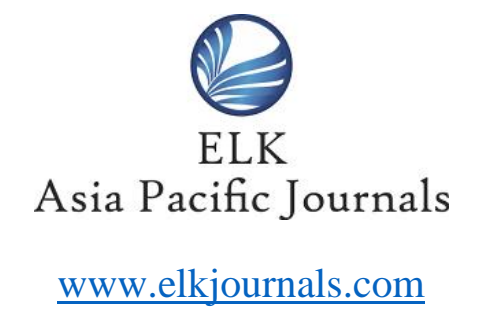

(D)For $1.00 \%$ wt. of Nano-Silica w.r.to Cement wt.Standard weight of Cement taken for 12 nos. Moulds $=12 X 200=2400$ gmsWeight of River Sand a/c to $1: 3$ ratio $=3 X 12 \times 200=7200 \mathrm{gms}$. Weight of Water added (comes to be) $=(30 / 4+3)$ $(2400+7200) / 100=1008 \mathrm{gms} \quad$ (ml.) $1.00 \%$ $\mathrm{XTX}=1.00 / 100 \mathrm{X} 2400=24 \mathrm{gms}$ of Nano-

Silica required $\equiv 59 \mathrm{gms}$ of $\mathrm{XTX} \equiv 50.78 \mathrm{ml}$. of XTX.

(@\% wt. of solid content in XTX=40.74\%; Density $(\mathrm{XTX})=1.16 \mathrm{gms} / \mathrm{cc}$. $)$ Net Water added $=1008-50.78=957.22 \mathrm{ml}$.

(E)For $1.25 \%$ wt. of Nano-Silica w.r.to Cement wt.Standard weight of Cement taken for 12 nos. Moulds $=12 X 200=2400$ gmsWeight of River Sand a/c to $1: 3$ ratio $=3 \times 12 X 200=7200 \mathrm{gms}$. Weight of Water added (comes to be) $=(30 / 4+3)$ $(2400+7200) / 100=1008 \mathrm{gms} \quad$ (ml.) $1.25 \%$ $\mathrm{XTX}=1.25 / 100 \mathrm{X} 2400=30 \mathrm{gms}$ of Nano-

Silica required $\equiv \quad 76.37 \mathrm{gms}$ of XTX $\equiv 63.5 \mathrm{ml}$.of XTX.

(@ \% wt. of solid content in XTX=40.74\%; Density $(\mathrm{XTX})=1.16 \mathrm{gms} / \mathrm{cc}$. $)$ Net Water added $=1008-63.5 \sim 945 \mathrm{ml}$.

(F)For 1.5\% wt. of Nano-Silica w.r.to Cement wt.Standard weight of Cement taken for 12 nos. Moulds $=12$ X200 $=2400 \mathrm{gms}$ Weight of
River Sand a/c to $1: 3$ ratio $=3 X 12 X 200=7200 \mathrm{gms}$. Weight of Water added (comes to be) $=(30 / 4+3)$ $(2400+7200) / 100=1008 \mathrm{gms} \quad$ (ml.) $1.5 \%$ XFXLa $=1.5 / 100 X 2400=36 \mathrm{gms}$ of Nano-

Silica required $\equiv \quad 85.85 \mathrm{gms}$ of $\mathrm{XFXLa} \equiv 69.23 \mathrm{ml}$. of

XFXLa.(@\% wt. of solid content in XFXLa=41.935\%; Density (XFXLa) $=1.24 \mathrm{gms} / \mathrm{cc}$.) Net Water added $=1008$ 69.23 938.76ml.

(II)The second test procedure involved testing CarbonNanotubes(Multiwalled,Industrial Grade - Supplied by M/s NANOSHEL,Panchkula,Haryana,India) dispersed in Superplasticizer( Polycarboxylate Ether(PCE) supplied by CHRYSO at $2 \%$ by wt. of cement ) in an optimum dosage $(0.02 \%$ by wt. of cement as per Literature Review) in Ordinary Portland Cement(OPC-Ambuja make) in a compression testing machine.

Test Procedure (II): Mortar cubes of $70.7 \mathrm{mmX} 70.7 \mathrm{mmX} 70.7 \mathrm{~mm}$ dimensions are filled with 1 part of Cement +3 parts of River Sand with Water added, according to the standard formula $\mathrm{P}^{\mathrm{ec}}=(\mathrm{P} / 4+3)(1$ part Cement+3partsSand).Here $\mathrm{P}^{\mathrm{ee}}=$ Quantity of water \& $\mathrm{P}=\mathrm{Consistency}$ of Cement used.i.e., amount of water used to make $300 \mathrm{gms}$ 
Asia Pacific Journals

www.elkjournals.com

cement paste to support a penetration of 5$7 \mathrm{~mm}$ in a standard Vicat mould with a Vicat needle. Now we would be testing the Compressive Strength of both composite \& ordinary Cement Mortar after 1day, 3days, 7days, 28days, 90days, 180days, 365days ordinary curing in a COMPRESSION CUBECRUSHING/TESTING M/C.

\subsection{TEST RESULTS -}

The following Table1 shows the Test Results obtained for $\mathrm{nS}$ embedment.

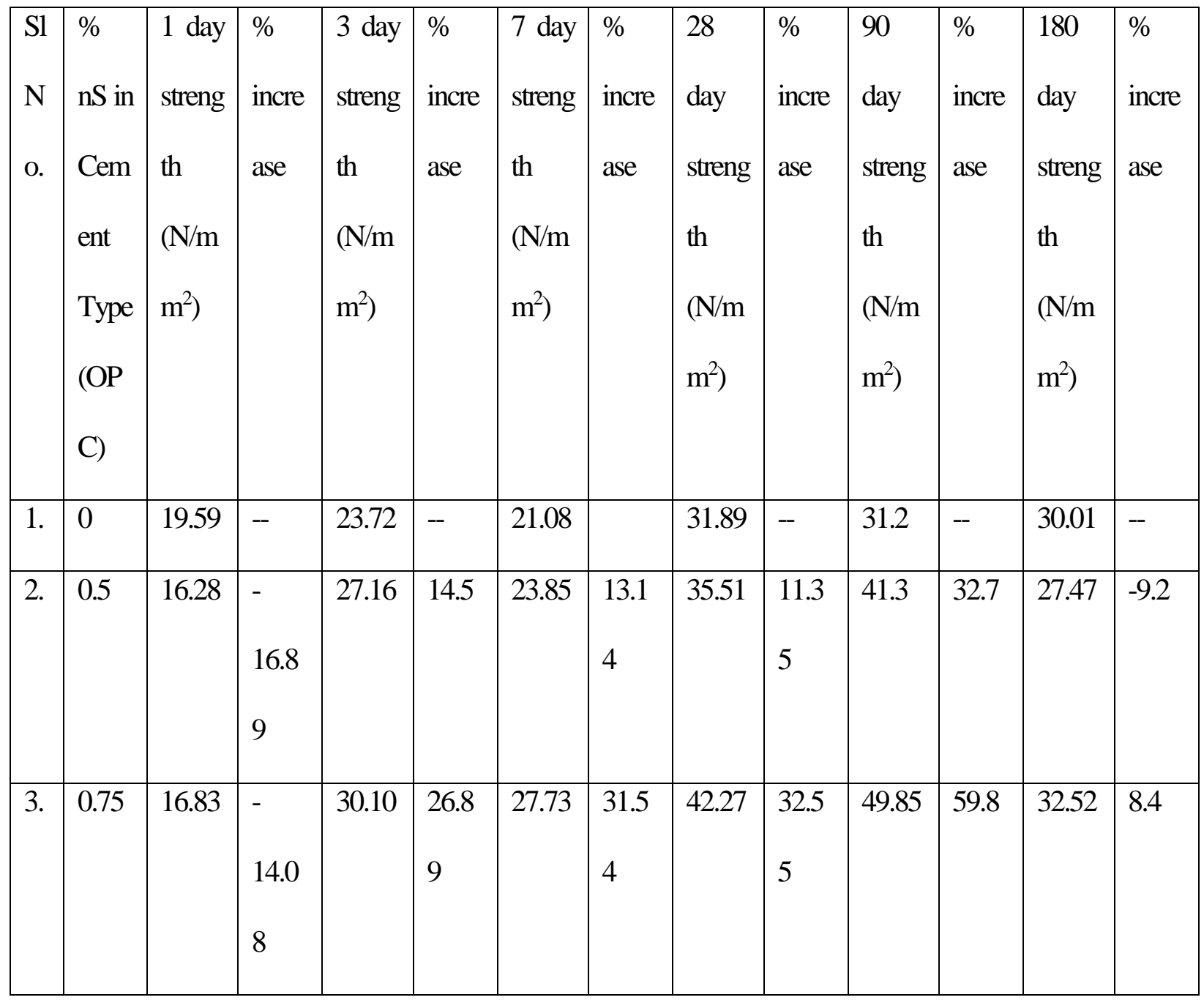




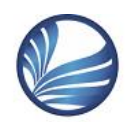

ELK

Asia Pacific Journals

www.elkjournals.com

\begin{tabular}{|l|l|l|l|l|l|l|l|l|l|l|l|l|l|}
\hline 4. & 1.0 & 18.36 & -6.27 & 19.38 & - & 25.07 & 18.9 & 37.36 & 17.1 & 42.98 & 37.7 & 33.68 & 12.2 \\
\hline 5. & 1.25 & 20.16 & 2.91 & 27.54 & 16.1 & 23.17 & 9.91 & 30.85 & 3.26 & 39.45 & 26.4 & 35.24 & 17.4 \\
\hline 6. & 1.5 & 20.69 & 5.62 & 23.35 & -1.56 & 23.81 & 12.9 & 37.79 & 18.5 & 33.42 & 7.12 & 31.23 & 4.07 \\
\hline
\end{tabular}

The following Table 2 shows the Test Results obtained for CNT embedment.

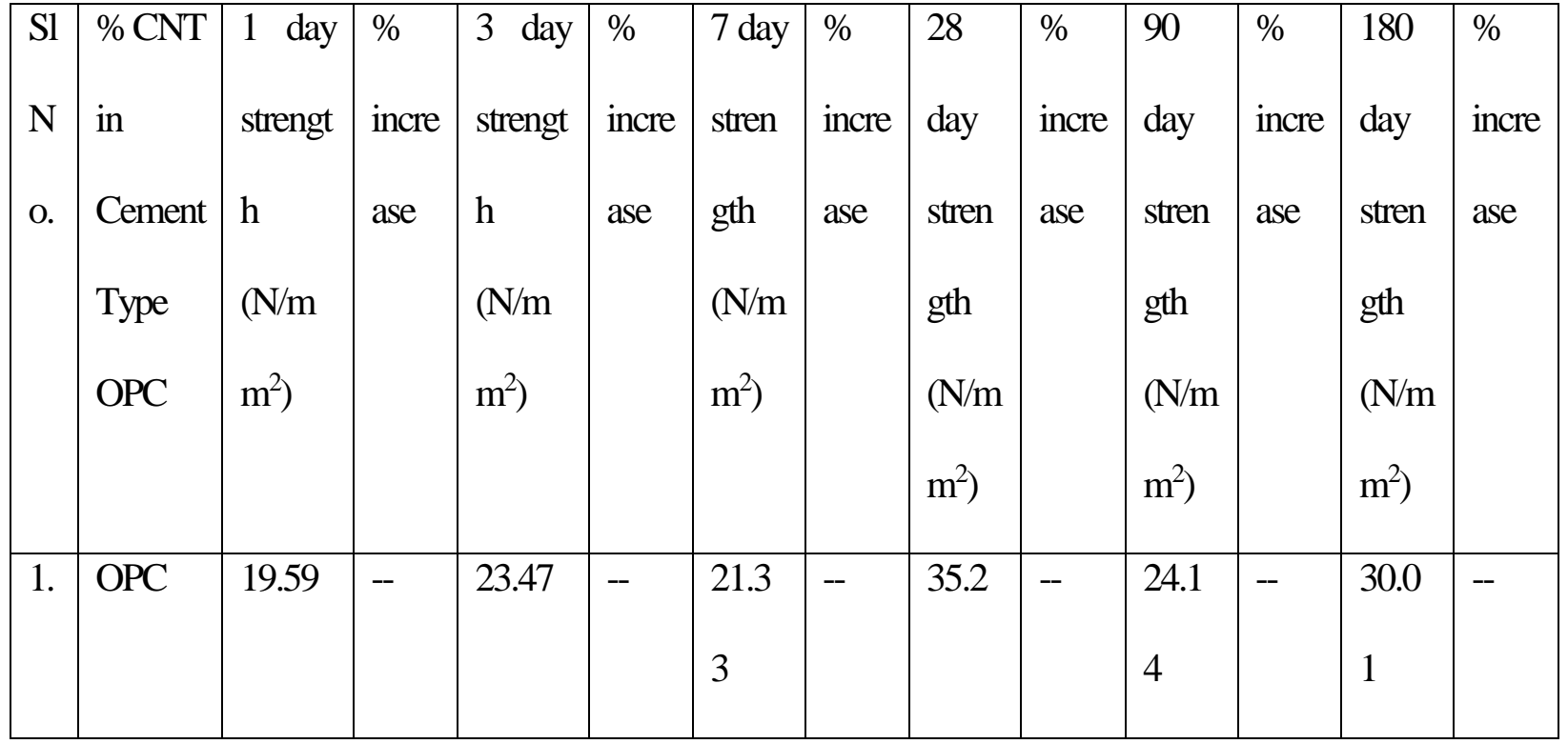




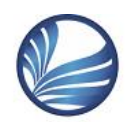

ELK

Asia Pacific Journals

www.elkjournals.com

\begin{tabular}{|c|c|c|c|c|c|c|c|c|c|c|c|c|}
\hline 2. & $\begin{array}{l}\text { OPC(1 } \\
\% \\
\text { PCE) }\end{array}$ & $\begin{array}{l}\text { Cubes } \\
\text { could't } \\
\text { be } \\
\text { demo } \\
\text { ulded }\end{array}$ & $\begin{array}{l}\text { Cubes } \\
\text { could't } \\
\text { be } \\
\text { demo } \\
\text { ulded }\end{array}$ & & $\begin{array}{l}18.8 \\
8\end{array}$ & $\begin{array}{l}- \\
10.4\end{array}$ & $\begin{array}{l}28.7 \\
3\end{array}$ & $\begin{array}{l}- \\
9.91\end{array}$ & $\begin{array}{l}36.0 \\
3\end{array}$ & $\begin{array}{l}15.4 \\
8\end{array}$ & $\begin{array}{l}33.2 \\
5\end{array}$ & 10 \\
\hline 3. & $\begin{array}{l}\text { OPC(1 } \\
\% \\
\text { PCE+0 } \\
.02 \% \\
\text { CNT) }\end{array}$ & $\begin{array}{l}\text { Cubes } \\
\text { could't } \\
\text { be } \\
\text { demo } \\
\text { ulded }\end{array}$ & 11.03 & $\begin{array}{l}- \\
53.5\end{array}$ & $\begin{array}{l}17.6 \\
9\end{array}$ & $\begin{array}{l}- \\
16.1\end{array}$ & $\begin{array}{l}43.7 \\
5\end{array}$ & 37.2 & $\begin{array}{l}35.5 \\
9\end{array}$ & $\begin{array}{l}14.0 \\
7\end{array}$ & $\begin{array}{l}30.8 \\
9\end{array}$ & 3 \\
\hline 4. & $\begin{array}{l}\text { OPC(1 } \\
\% \\
\text { PCE+0 } \\
.05 \% \\
\text { CNT)) }\end{array}$ & $\begin{array}{l}\text { Cubes } \\
\text { could't } \\
\text { be } \\
\text { demo } \\
\text { ulded }\end{array}$ & 5.38 & $\begin{array}{l}- \\
66.4\end{array}$ & $\begin{array}{l}27.1 \\
9\end{array}$ & 28.9 & $\begin{array}{l}34.8 \\
8\end{array}$ & 9.37 & $\begin{array}{l}31.8 \\
5\end{array}$ & 2.08 & $\begin{array}{l}38.5 \\
5\end{array}$ & $\begin{array}{l}23.5 \\
5\end{array}$ \\
\hline 5. & $\begin{array}{l}\text { OPC }(1 \\
\% \\
\text { PCE+0 }\end{array}$ & $\begin{array}{l}\text { Cubes } \\
\text { could't } \\
\text { be }\end{array}$ & 14.21 & $\begin{array}{l}- \\
40.1\end{array}$ & $\begin{array}{l}21.6 \\
9\end{array}$ & 2.89 & $\begin{array}{l}24.8 \\
3\end{array}$ & $\begin{array}{l}- \\
22.1 \\
4\end{array}$ & 31.5 & 0.96 & $\begin{array}{l}30.1 \\
6\end{array}$ & $\begin{array}{l}- \\
3.33\end{array}$ \\
\hline
\end{tabular}




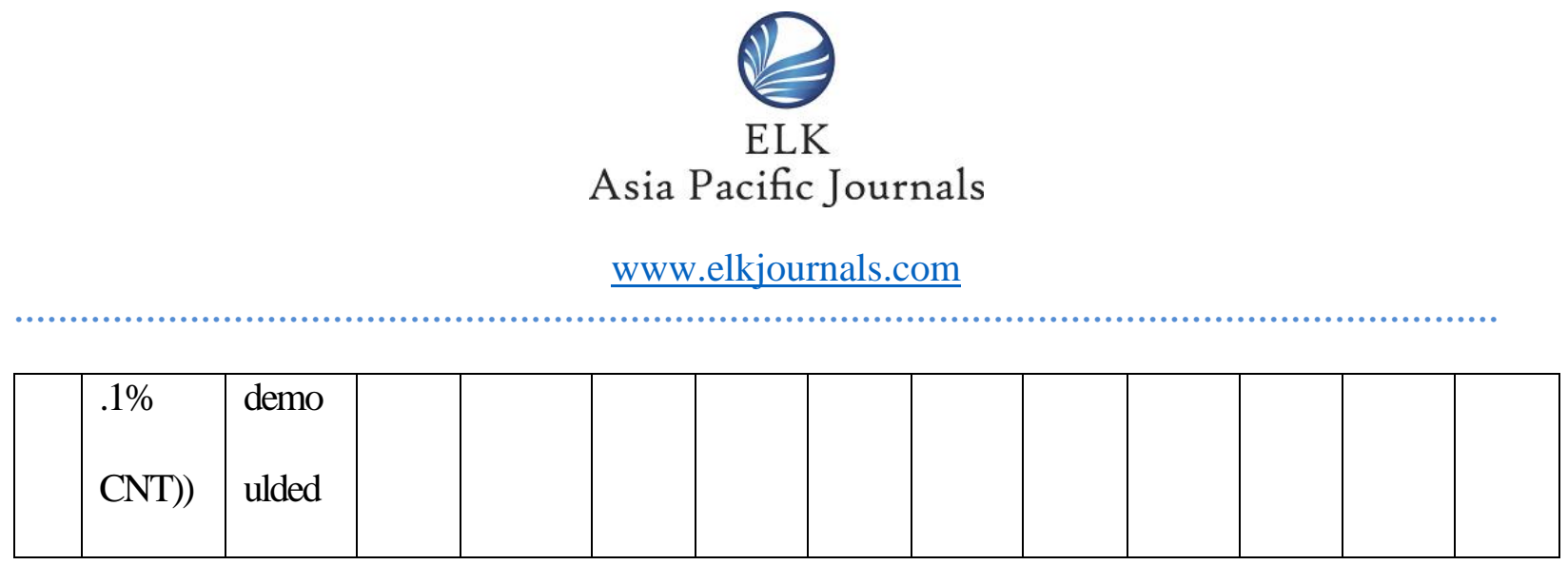

\subsection{Discussion of Test Results:-}

Table 1 shows the compressive strength results of Ordinary Portland Cement for various percentages of nano-silica. For 1 day, the maximum strength has been observed for $1.5 \% \mathrm{nS}$ with an increase of $5.62 \%$ from the controlled specimen. For 3 days, the maximum strength has been observed for $0.75 \% \mathrm{nS}$ with an increase of $26.89 \%$ from the controlled specimen. For 7 days also, the maximum strength has been observed for $0.75 \% \mathrm{nS}$ increasing about $27.73 \%$ from the controlled specimen. For 28 days again, the maximum strength has been observed for $0.75 \% \mathrm{nS}$ with an increase of $17.15 \%$ from the controlled specimen. For 90 days, the maximum strength has been observed for $1.0 \% \mathrm{nS}$ with an increase of $35.2 \%$ from the controlled specimen. For 180 days the maximum strength was found for $1.25 \% \mathrm{nS}$ with an increase of $17.4 \%$.

Table 2 shows the compressive strength results of Ordinary Portland Cement for various percentages of carbon Nanotubes dispersed in PCE. At 1 day no cube was found to get demoulded for testing. The 28 days maximum strength was $43.75 \mathrm{MPa}$ and was found for $0.02 \%$ CNTs with a $37 \%$ increase w.r.to ordinary cement mortar. However, at latter ages the strength decreases.

"Soon researchers will bring us devices that can translate foreign languages as fast as you can talk; materials 10 times stronger than steel at a fraction of the weight; and, this is unbelievable to me, molecular computers the size of at eardrop with the power of today's fastest supercomputers."

---- Bill Clinton.

\subsection{CONCLUSIONS-}

1. An optimization of $\mathrm{nS}$ was found at $0.75 \%$ of cement wt. for maximum mechanical strength at 28 days.

2. An optimization of CNTs was found at $0.02 \%$ of cement wt. at $1 \%$ Super plasticizer w.r.to cement wt. for 


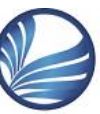

ELK

Asia Pacific Journals

www.elkjournals.com

maximum mechanical strength at 28 days.

3. The strength decreases with nano embedment at later ages. This may be attributed to the fact that Nanoparticles tend to get oxidized at that period of time.

\subsection{REFERENCES}

[1] Belkowitz,S.J. \& Armentrout, D.(2010), „An Investigation of Nano Silica in the CementHydration Processee, Concrete Sustainability Conference, National Ready Mixed Concrete Association, Europe.

[2] Quercia,G. \& Brouwers,H.J..(2010), Application of nano-silica $(\mathrm{nS})$ in concrete mixtures "8thfib PhD Symposium in Kgs. Lyngby, Denmark, June 2 - 23, 2010.

[3] Valipour,M. et al.(2010), „Comparative study of nano-SiO and silica fume on gas permeability of high performance concrete (HPC) $)^{\text {ee }}$ C 2010 Korea Concrete Institute.

[4] Kumar,S. et al(2012), „Effect of Multiwalled Carbon Nanotubes on
Mechanical Strength ofCement Paste ${ }^{e e}$,Journal of Materials in Civil Engineering,24(1),84-91.

[5] Maheswaran,S. et al(2012). „An Overview on the Influence of Nano Silica in Concretea Research Initiative ${ }^{\text {ee }}$, Research Journal of Recent Sciences, Vol. 2(ISC-2012), 17-24.

[6] Yang,H.(2012), ,Strength and Shrinkage Property of Nano Silica Powder Concrete $^{\text {ee }}$ 2ndInternational Conference on Electronic \& Mechanical Engineering $\&$ InformationTechnology,China.

[7] Yuvraj,S.(2012), „Experimental Research On Improvement Of Concrete Strength And Enhancing The Resisting Property Of Co rrosion And Permeability ByThe Use Of Nano Silica Flyashed Concrete ${ }^{e e}$ International Journal of Emerging Technology andAdvanced Engineering, Vol. 2, Issue 6, June 2012.

[8] Abyaneh,M.R.J. et al(2013). „Effects of Nano-Silica on Permeability of Concrete andSteel Bars Reinforcement Corrosion", Australian Journal of Basic and Applied Sciences, 464-467, 2013. 
ISSN 2394-9341 (Online); Volume 1 Issue 2 (2015)

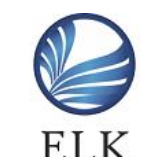

Asia Pacific Journals

www.elkjournals.com

[9] Madhavi, T. Ch. et al (2013), „Effect of Multiwalled Carbon Nanotubes on MechanicalProperties of Concrete ${ }^{e e}$,International Journal of Scientific Research,Vol.2,Issue
[10] Rajmane,N.P. et al(2013), ${ }^{, c} E f f e c t$ of A ddition of Nano-Silica to Portland Cement Mortar, with and without Silica Fume ${ }^{\text {ec }}$,ICI Journal,vol 14,No.2,JulySeptember,7-16

6,June2013,166-168. 